\title{
PELUANG TUMBUH, STRUKTUR MODAL, KEPEMILIKAN MANAJERIAL TERHADAP PROFITABILITAS DAN NILAI PERUSAHAAN
}

\author{
Tia Alviani \\ tiaalv3@gmail.com \\ Mujbah Achyar Sufyani \\ Universitas Pasundan \\ Jl. Tamansari No. 6-8, Bandung 40116
}

diterima: 20/12/2019; direvisi: 26/1/2020; disetujui: 27/2/2020

\begin{abstract}
High firm value can be increased shareholder's wealth, make investor interested. This study aims were to determine the effect of growth opportunity, capital structure and managerial ownership to profitability and impact to firm value. Quantitative method in this study with population of 82 service companies in the property, real estate, and building construction sectors listed on the Indonesia Stock Exchange for the period 2012 - 2018. The sampling technique used was purposive sampling, and choosed 13 companies were also selected. The type of data used is secondary data with data analysis using multiple linear regression. The results of this study indicated that simultaneously growth opportunities, capital structure, and managerial ownership effect profitability of 49.2\%. Partially, growth opportunities, capital structure, and managerial ownership have a positive and significant effect on profitability. Financial performance has a negative and significant effect on firm value.
\end{abstract}

Keywords: growth opportunities; capital structure; managerial ownership; profitability; firm value

\begin{abstract}
Abstrak
Nilai perusahaan yang tinggi dapat meningkatkan kemakmuran pemegang saham, sehingga menarik minat investor. Penelitian ini bertujuan untuk mengetahui pengaruh peluang tumbuh, struktur modal, dan kepemilikan manajerial terhadap profitabilitas serta dampaknya terhadap nilai perusahaan. Metode kuantitatif digunakan dengan populasi 82 perusahaan jasa sektor properti, real estate, dan konstruksi bangunan yang terdaftar di Bursa Efek Indonesia periode 2012 2018. Teknik pengambilan sampel yang digunakan adalah purposive sampling, dan terpilih 13 perusahaan. Data yang digunakan adalah data sekunder dengan analisis data menggunakan model regresi linier berganda. Hasil penelitian menunjukkan bahwa secara simultan peluang tumbuh, strukur modal, dan kepemilikan manajerial berpengaruh signifikan terhadap profitabilitas sebesar $49,2 \%$. Secara parsial, peluang tumbuh, strukur modal, dan kepemilikan manajerial berpengaruh positif dan signifikan terhadap profitabilitas. Profitabilitas berpengaruh negatif dan signifikan terhadap nilai perusahaan.
\end{abstract}

Kata Kunci: kesempatan tumbuh; struktur modal; kepemilikan manajerial; profitabilitas; nilai perusahaan 


\section{PENDAHULUAN}

Kepercayaan investor dilihat dari kemampuan perusahaan mempertahankan harga saham di pasar modal. Harga saham yang stabil akan meningkatkan kepercayaan investor. Selain untuk mendapatkan keuntungan, perusahaan memiliki tujuan untuk memaksimumkan kemakmuran pemilik. Meningkatnya harga saham maka akan meningkatkan kemakmuran para pemegang saham.

Nilai perusahaan dapat dicerminkan dari harga saham. Nilai perusahaan dapat dikatakan tinggi apabila harga saham juga tinggi, akan meningkatkan kepercayaan pemegang saham atau investor terhadap kinerja keuangan dan prospek perusahaan di masa mendatang. (Brigham \& Houston, 2019) menunjukkan beberapa pendekatan analisis rasio dalam penilaian market value, terdiri dari pendekatan price earning ratio (PER), price book value ratio (PBV), market book ratio (MBR), dividend yield ratio, dan dividend payout ratio (DPR). Proksi yang digunakan dalam penelitian ini adalah PER, rasio harga per lembar saham terhadap laba per lembar saham, menunjukkan jumlah yang bersedia dibayarkan investor untuk setiap laba yang dilaporkan.

PER merupakan aspek yang menarik, karena merupakan rasio pengukuran yang paling komprehensif tentang prestasi perusahaan yang mencerminkan perpaduan antara pengaruh rasio risiko dan pengembalian. PER juga merupakan cerminan dari keberanian investor untuk membayar setiap rupiah harga saham untuk setiap rupiah laba yang dihasilkan. Nilai perusahaan yang diukur dengan PER menggambarkan keuntungan perusahaan atau emiten saham terhadap harga sahamnya, menunjukkan besarnya rupiah yang harus dibayarkan investor untuk memperoleh satu rupiah laba perusahaan. Semakin tinggi pertumbuhan laba, maka nilai PER akan semakin tinggi (Dwipartha, 2011).

Pemegang saham perlu mengetahui harga yang tercantum pada saham sebuah perusahaan apakah terlalu tinggi atau sudah terlalu rendah untuk keputusan investasi. Hal tersebut dapat dilihat dari perhitungan PER pada perusahaan. Semakin tinggi nilai PER, berarti harga saham yang dimiliki perusahaan tersebut akan semakin mahal. Sebaliknya, semakin rendah nilai PER, maka harga saham perusahaan akan semakin murah.

Pemilihan perusahaan yang terdaftar di Bursa Efek Indonesia (BEI) dalam penelitian ini akan dimulai dengan membandingkan nilai PER industri pada setiap sektor yang ada pada BEI. Perbandingan ini dilakukan pada seluruh sektor perusahaan yang terdaftar di BEI. Langkah awal yang dilakukan adalah menghitung data PER industri pada 9 sektor yang terdaftar di BEI. PER Industri sangat penting karena dapat menentukan persepsi investor akan perusahaan yang diminati dalam berinvestasi. PER industri akan menunjukkan persepsi, PER dikatakan rendah apabila PER berada di bawah PER industri, dan sebaliknya, PER dikatakan mahal apabila berada di atas PER industri sejenis. PER setiap sektor pada periode 2012 - 2018 disajikan pada Tabel 1, menunjukkan adanya fluktuasi nilai perusahaan.

Kondisi nilai perusahaan dapat diketahui lebih jelas melalui rata-rata perubahan PER per sektor periode 2012 - 2018 yang disajikan dalam Tabel 2. Rata-rata variasi perubahan PER yang tertinggi adalah sektor pertanian, sedangkan terendah berada pada sektor properti, real estate, dan konstruksi bangunan. Pada dasarnya, pertumbuhan industri serta perkembangan laba perusahaan akan sangat berpengaruh terhadap penentuan nilai perusahaan yang akan dilakukan para pelaku pasar terutama investor. Selain berkaitan dengan harga saham yang ditawarkan, investor akan mempertimbangkan perkembangan laba perusahaan melalui nilai PER. PER merupakan alat bantu paling mudah dipahami untuk mengetahui jumlah laba yang akan investor dapatkan berdasarkan harga saham yang ditawarkan perusahaan. Perkembangan nilai perusahaan menggunakan nilai rata-rata PER pada perusahaan jasa sektor properti, real estate, dan konstruksi bangunan yang terdaftar di BEI periode 2012 - 2018 ditunjukkan pada Gambar 1.

Peningkatan PER dapat disebabkan karena penurunan earning per share (EPS) yang jumlahnya lebih kecil dibandingkan harga saham sehingga nilai PER mengalami peningkatan. Sebaliknya penurunan nilai PER disebabkan karena peningkatan EPS yang lebih besar daripada harga sahamnya. Tahun 2018 pada kuartal ke-3 menunjukkan rata-rata PER tertinggi, namun pada kuartal ke-4 penurunan hingga negatif. PER dengan angka negatif mengindikasikan bahwa perusahaan dalam kondisi yang buruk, dalam hal ini perusahaan memiliki pengembalian atau EPS yang bernilai negatif.

Penurunan nilai perusahan dapat menimbulkan permasalahan, seperti kehilangan daya tarik di pasar modal yang akan membuat ketidakpercayaan investor. Hadirnya investor dapat meningkatkan kinerja keuangan, karena investor akan memberikan suntikan dana kepada perusahaan. Berdasarkan laporan tahunan, investor dapat melihat kinerja keuangan yang mencerminkan efektivitas dan efisiensi dalam mengelola dana yang bersumber dari dalam maupun luar perusahaan pada periode tertentu (Tjandrakirana D. P, 2014).

Gambar 1 menunjukkan bahwa pada tahun 2012 2018 perusahaan jasa sektor peroperti, real estate, dan kontruksi bangunan memiliki PER yang cenderung menurun. Nilai perusahaan juga dapat memberikan gambaran mengenai kinerja keuangan. Calon investor akan mempertimbangkan analisis rasio keuangan untuk keputusan investasi. Jika analisis rasio keuangan perusahaan baik, maka para calon investor akan menginvestasikan modalnya. 
Profitabilitas menunjukkan sejauh mana perusahaan dapat tumbuh dan berkembang dengan memanfaatkan sumber daya yang dimilikinya. Investor akan tertarik berinvestasi pada perusahaan yang memiliki profitabilitas tinggi. Profitabilitas dianggap sebagai tolok ukur suatu perusahaan dalam menghasilkan tingkat pengembalian yang diinginkan. Perusahaan maupun pemegang saham akan memperhitungkan keuntungan yang diperoleh dengan pengorbanan yang dilakukan. Investor ingin mendapatkan pengembalian yang tinggi. Semakin baik rasio profitabilitas maka semakin baik kemampuan perolehan keuntungan perusahaan (Kasmir, 2018).

Rasio profitabilitas dapat diukur dengan gross profit margin (GPM), net profit margin (NPM), return on assets (ROA), dan return on equity (ROE). Peneliti menggunakan ROE sebagai ukuran kinerja keuangan, karena merupakan aktivitas mendapatkan laba dari penggunaan dana perusahaan yang diinvestasikan pemegang saham. ROE adalah rasio laba bersih terhadap ekuitas saham biasa (Gitman, et, al. 2015). ROE tinggi menunjukkan kemampuan perusahaan dalam menghasilkan keuntungan yang tinggi bagi pemegang saham dan menunjukkan pertumbuhan di masa datang. ROE yang tinggi menunjukkan kinerja keuangan perusahaan juga baik, mengakibatkan investor tertarik menanamkan modal (Muntiah, 2012). Gambar 2 adalah grafik rata-rata ROE pada perusahaan jasa sektor properti, real estate, dan konstruksi bangunan yang terdaftar di BEI periode 2012-2018.

ROE pada perusahaan jasa sektor properti, real estate, dan konstruksi bangunan mengalami fluktuasi yang cenderung menurun. Peningkatan ROE dapat disebabkan karena laba bersih yang meningkat dengan tingkat ekuitas tetap atau menurun. Beberapa penelitian menunjukkan hasil yang beragam antara pengaruh profitabilitas terhadap nilai perusahaan. Penelitian (Jusriani \& Rahardjo, 2013), (Mardiyati, Umi; Ahmad, Gatot Nazir; Putri, 2012), (Rizqia et al., 2013), (Mayogi, 2016), dan (Prasetyorini, 2013) menunjukkan bahwa profitabilitas memiliki pengaruh yang positif dan signifikan terhadap nilai perusahaan. Sedangkan penelitian (Kusna \& Setijani, 2018) profitabilitas diproksikan dengan ROA dan ROE berpengaruh negatif signifikan terhadap nilai perusahaan yang diukur dengan PBV, PER, dan Tobin's Q. Menurut (Awan et al., 2018), (Palupi \& Hendiarto, 2018), (Putri \& Rachmawati, 2018), dan (Rahayu dan Asandimitra, 2014) menunjukkan hasil penelitian yang berbeda, yaitu profitabilitas tidak memiliki pengaruh siginifikan terhadap nilai perusahaan.

Peluang tumbuh (growth opportunity) adalah kemungkinan pertumbuhan di masa datang, yaitu pilihan investasi yang diharapkan menghasilkan keuntungan lebih besar. Peluang ini memungkinkan perusahaan dapat meningkatkan pendapatan dari pemanfaatan aset yang tersedia. Peluang tumbuh ditandai dengan pertumbuhan perputaran keuangan yang positif sehingga memungkinkan perluasan usaha. Peluang tumbuh yang besar dapat dijadikan sebagai ukuran tercapainya kemakmuran para pemegang saham (Kusna \& Setijani, 2018). Pertumbuhan perusahaan akan membuat investor tertarik terhadap investasi, karena menunjukkan prospek yang menguntungkan di masa depan, sehingga memiliki harapan akan mendapatkan rate of return atas investasi yang dilakukan.

Peluang tumbuh dapat diukur menggunakan price earning ratio (PER) dan menggunakan growth assets. Penelitian ini menggunakan growth asset. Gambar 3 menunjukkan grafik rata-rata peluang tumbuh pada perusahaan jasa sektor infrastruktur, utilitas dan transportasi yang terdaftar di BEI periode 20122018 berdasarkan perhitungan growth assets yang menunjukkan pergerakan perubahan pada total aset pada setiap kuartal selama tahun berjalan.

Peluang tumbuh mengalami fluktuasi. Perusahaan yang mempunyai prediksi akan mengalami pertumbuhan tinggi di masa mendatang akan lebih memilih menggunakan saham untuk mendanai operasinya (Indasari \& Yadnyana, 2018). Penelitian (Saraswati, 2016) dan (Romadon dan Sulistyo, 2018) menunjukkan kesempatan tumbuh memiliki hubungan yang positif dan signifikan terhadap profitabilitas. Penelitian (Sardo \& Serrasqueiro, 2018) menunjukkan terdapat hubungan positif peluang tumbuh dan kinerja keuangan dapat ditingkatkan dengan penggunaan modal intelektual perusahaan yang efisien. Hasil berbeda dikemukakan (Khairani. H, 2015) menjelaskan peluang tumbuh tidak berpengaruh langsung dan signifikan terhadap profitabilitas perusahaan.

Faktor lain yang juga mempengaruhi profitabilitas yaitu sumber dana yang digunakan untuk operasi. Pendanaan sangat penting bagi suatu perusahaan karena melibatkan banyak pihak seperti kreditur, pemegang saham, dan manajemen. Perusahaan memerlukan tambahan modal dalam rangka pengembangan bisnisnya. Keputusan pendanaan berpengaruh terhadap aktivitas operasi dan meningkatkan risiko perusahaan. Struktur modal merupakan masalah yang penting karena mempunyai efek langsung terhadap posisi finansial perusahaan, yang pada akhirnya akan mempengaruhi nilai perusahaan (Susanto, 2016) Masuknya emiten ke pasar modal, memungkinkan mereka bisa memilih berbagai alternatif pendanaan yang tersedia, namun ekuitas akan jadi alternatif yang paling menarik.

Struktur modal dapat diukur menggunakan rasio leverage yaitu diantaranya, debt to total assets (DAR), dan debt to equity ratio (DER). DER menunjukkan presentase penyediaan dana oleh pemegang saham terhadap pemberi pinjaman. DER merupakan rasio penting untuk diperhatikan pada saat memeriksa kesehatan keuangan perusahaan. Kreditur dan investor biasanya memilih DER yang rendah karena kepentingannya lebih terlindungi jika terjadi penurunan bisnis perusahaan. DER yang tinggi menunjukkan 
bahwa perusahaan mungkin tidak dapat menghasilkan uang yang cukup untuk memenuhi kewajiban hutangnya, sehingga berdampak semakin besar beban terhadap kreditur, artinya modal perusahaan tergantung dengan pihak luar. Besarnya beban hutang ini akan mengurangi jumlah laba yang diterima perusahaan. DER yang rendah dapat menandakan bahwa perusahaan tidak memanfaatkan peningkatan labanya secara maksimal.

Gambar 4 menunjukkan grafik rata-rata struktur modal pada perusahaan jasa sektor properti, real estate, dan konstruksi bangunan yang terdaftar di BEI periode 2012 - 2018 berdasarkan perhitungan DER. DER menunjukkan pergerakan yang fluktuatif. Semakin besar DER menunjukkan semakin besarnya penggunaan hutang perusahaan dibandingkan modal sendiri. Penggunaan hutang diharapkan akan menaikkan tingkat pengembalian bagi pemegang saham. DER megalami penurunan karena perusahaan memiliki hutang yang lebih kecil. Pada tingkat hutang yang optimal, diharapkan nilai perusahaan dapat mencapai nilai maksimal, begitu pula sebaliknya apabila terjadi tingkat perubahan hutang sampai melewati tingkat optimal atau biaya kebangkrutan, hutang akan mempunyai efek negatif terhadap nilai perusahaan (Ananda, 2016). Penelitian (Rifai et al., 2015) menunjukkan struktur modal memiliki hubungan negatif signifikan terhadap profitabilitas. Hal ini sejalan dengan penelitian (Kusna \& Setijani, 2018) menunjukkan struktur modal memiliki pengaruh negatif dan signifikan terhadap profitabilitas dan nilai perusahaan.

Komite Nasional Kebijakan Corporate Governance (KNKCG) berpendapat bahwa perusahaan di Indonesia mempunyai tanggung jawab untuk menerapkan standar perusahaan baik yang telah diterapkan di tingkat internasional. Tata kelola perusahaan merupakan upaya untuk mencari cara terbaik dalam menjalankan perusahaan, dimana kebijakan dan peraturan yang ada dalam corporate governance dapat digunakan untuk mengontrol manajemen. Hal ini tercermin ketika manajer melakukan pengambilan keputusan akan berusaha untuk tetap konsisten dengan tujuan yaitu kemakmuran pemegang saham dan nilai perusahaan.

Nilai perusahaan semakin penting bagi manajer dan juga investor untuk menentukan nilai sebenarnya dari perusahaan (Thi et al., 2018). Nilai perusahaan yang tinggi dapat meningkatkan kemakmuran pemegang saham, sehingga investor dapat menginvestasikan modalnya ke perusahaan tersebut. Untuk menginvestasikan modalnya, investor akan melakukan analisis pada laporan keuangan yang memperlihatkan kinerja keuangan perusahaan. Manajemen yang secara langsung terlibat di dalam mengelola perusahaan memiliki informasi yang lebih memadai dibanding investor. Investor cenderung menerima informasi hanya dari pihak manajemen melalui laporan keuangan tanpa mengetahui kondisi perusahaan yang sesungguhnya. Hal inilah yang menyebabkan munculnya agency theory (Thaharah \& Asyik, 2016).
Konflik dalam agency theory biasanya disebabkan oleh para pengambil keputusan yang tidak ikut serta dalam menanggung risiko sebagai akibat dari kesalahan pengambilan keputusan. Konflik antara pemilik saham dengan manajemen perusahaan dapat diminimalkan dengan cara manajer harus mejalankan perusahaan sesuai dengan kepentingan para pemegang saham begitupula dalam pengambilan keputusan oleh manajer harus disesuaikan dengan kepentingan pemegang saham.

Pemegang saham yang turut aktif terlibat dalam pengambilan keputusan (Direksi dan Komisaris) disebut dengan kepemilikan manajerial. Perusahaan dengan kepemilikan manajerial yang lebih tinggi mengurangi biaya tambahan mereka, sehingga konflik antara pemegang saham manajer dapat diselesaikan (Shahabu-Din \& Javid, 2011). Agency problem dapat diminalisir dengan adanya kepemilikan manajerial dalam suatu perusahaan. Peningkatan proporsi kepemilikan manajerial akan mengeliminasi perbedaan kepentingan sehingga kinerja keuangan semakin baik.

Kepemilikan manajerial akan mendorong perusahaan meningkatkan kinerja. Manajer yang juga pemegang saham akan bertindak sesuai dengan keinginan pemilik, karena termotivasi untuk meningkatkan kinerja dalam rangka menciptakan nilai perusahaan yang tinggi (Romadon dan Sulistyo, 2018). Gambar 5 adalah grafik rata-rata kepemilikan manajerial pada perusahaan jasa sektor properti, real estate, dan konstruksi bangunan yang terdaftar di BEI periode 2012-2018.

Kepemillikan manajerial mengalami penurunan karena perusahaan mengurangi pembagian saham kepada manajemen dibandingkan jumlah saham yang beredar. Penelitian (Hikmah and Fitria, 2019), dan (Rahman \& Reja, 2015) menunjukkan bahwa kepemilikan manajerial berpengaruh positif dan signifikan terhadap profitabilitas. Namun penelitian (Nopiani, Kadek Dian;Sulindawati, Luh Gede Erni; Sujana, 2015) menunjukkan GCG diproksikan dengan kepemilikan manajerial, ukuran dewan direksi, ukuran dewan komisaris, dan proporsi komisaris independen tidak berpengaruh terhadap kinerja keuangan. Penelitian (Zondi, 2015) dan (Muntiah, 2012) menunjukkan bahwa kepemilikan manajerial berpengaruh negatif terhadap profitabilitas. Penelitian (Khairani. H, 2015) menjelaskan struktur kepemilikan manajerial tidak berpengaruh signifikan terhadap profitabilitas perusahaan.

Tujuan penelitian ini adalah untuk: (1) mengetahui kondisi kesempatan tumbuh, struktur modal, kepemilikan manajerial, profitabilitas, dan nilai perusahaan, (2) besar pengaruh kesempatan tumbuh, struktur modal, dan kepemilikan manajerial secara simultan dan parsial terhadap profitabilitas, (3) besar pengaruh profitabilitas terhadap nilai perusahaan pada perusahaan jasa sektor properti, real estate, dan konstruksi bangunan yang terdaftar di Bursa Efek Indonesia periode 2012-2018. 


\section{METODE}

Metode penelitian yang digunakan adalah metode kuantitatif dengan pendekatan deskriptif dan verifikatif. Penelitian ini menggunakan data sekunder, yaitu laporan keuangan dari situs resmi BEI www.idx.co.id dan situs resmi perusahaan. Metode analisis data yang digunakan adalah analisis regresi linier berganda.

Jumlah populasi sebanyak 82 perusahaan. Penentuan sampel menggunakan teknik purposive sampling dengan kriteria: (1) Perusahaan jasa sektor properti, real estate, dan kontruksi bangunan yang sudah dan masih terdaftar di BEI selama periode 2012-2018, (2) menerbitkan laporan keuangan per-kuartal secara konsisten, (3) memiliki kepemilikan manajerial per-kuartal secara konsisten, (4) tidak mengalami kerugian. Perusahaan yang sesuai dengan kriteria pengambilan sampel dalam penelitian ini adalah sebanyak 13 perusahaan..

\section{HASIL}

Hasil pengolahan analisis regresi persamaan 1 ditunjukkan pada Tabel 3, dan untuk persamaan 2 pada Tabel 4. Hasil koefisien determinasi secara simultan untuk persamaan 1 ditunjukkan pada Tabel 5. Koefisien determinasi parsial dapat dilihat pada Tabel 6. Koefisien determinasi untuk persamaan 2 ditunjukkan pada Tabel 7.

Hasil uji F ditunjukkan pada Tabel 8, dapat diketahui bahwa peluang tumbuh, struktur modal, dan kepemilikan manajerial secara simultan dan parsial berpengaruh positif signifikan terhadap profitabilitas pada perusahaan jasa sektor properti, real estate, dan konstruksi bangunan.

\section{PEMBAHASAN}

Hasil uji hipotesis secara simultan menunjukkan bahwa peluang tumbuh, struktur modal, dan kepemilikan manajerial berpengaruh signifikan sebesar 49,2\% terhadap profitabilitas pada perusahaan jasa sektor properti, real estate, dan konstruksi bangunan yang terdaftar di BEI tahun 2012 - 2018. Perusahaan yang memanfaatkan total aset untuk meningkatkan investasi, penggunaan hutang, dan upaya menekan agency problem melalui kepemilikan manajerial dapat memberikan kontribusi terhadap keuntungan.

Kepemilikan manajerial memiliki kontribusi pengaruh terbesar, yaitu $30,02 \%$ dan signifikan terhadap profitabilitas, hal ini sejalan dengan penelitian (Pasaribu et al., 2016) dan (Sofyaningsih, Sri dan Hardiningsih, 2011). Kepemilikan manajerial adalah pemegang saham oleh manajemen yang secara aktif berperan dalam pengambilan keputusan. Kepemilikan manajerial dapat mensejajarkan antara kepentingan pemegang saham dengan manajer. Manajer ikut merasakan langsung manfaat dari keputusan yang diambil dan menanggung risiko apabila ada kerugian yang timbul sebagai konsekuensi dari pengambilan keputusan yang salah.

Pengaruh struktur modal positif dan signifikan terhadap profitabilitas sebesar $8,98 \%$. Hal ini sejalan dengan teori struktur modal pendekatan laba operasi bersih (net operating income approach) yang menjelaskan bahwa penggunaan hutang semakin besar oleh pemilik modal dilihat sebagai peningkatan risiko perusahaan, maka tingkat keuntungan yang disyaratkan oleh pemilik modal juga akan meningkat. Sebagai konsekuensinya, biaya modal rata-rata tertimbang tidak mengalami perubahan, sehingga keputusan struktur modal menjadi tidak ada artinya.

Koefisien determinasi secara parsial menyatakan bahwa peluang tumbuh memiliki pengaruh positif dan signifikan terhadap profitabilitas sebesar 10,23\%. Total aset yang tinggi menunjukkan bahwa perusahaan memiliki kemampuan untuk mendanai usaha dengan baik, oleh karena itu akan meningkatkan kepercayaan investor. Biasanya perusahaan yang memiliki peluang tumbuh tinggi maka akan memiliki profitabilitas yang tinggi. Perusahaan yang mempunyai peluang tumbuh tinggi mempunyai nilai investasi dalam jumlah yang besar, terutama dalam aktiva tetap yang umur ekonomisnya lebih dari satu tahun. Hasil ini sejalan dengan penelitian yang dilakukan (Saraswati, 2016) dan (Romadon dan Sulistyo, 2018).

Hasil pengujian koefisien determinasi secara parsial menyatakan bahwa, struktur modal memiliki pengaruh positif dan signifikan terhadap profitabilitas sebesar $8,98 \%$. Profitabilitas yang diukur dengan ROE menunjukkan kemampuan efektivitas dan efisiensi perusahaan dalam menghasilkan laba bersih. Semakin tinggi ROE menggambarkan semakin efektif dan efisiennya perusahaan dalam mengelola modal yang diinvestasikan oleh investor untuk menghasilkan keuntungan maupun arus kas. Perusahaan yang memiliki tingkat ROE tinggi menunjukkan adanya jaminan pengembalian atas modal sendiri yang telah diinvestasikan. ROE tinggi juga menunjukkan prospek perusahaan yang baik di masa depan sehingga dapat meningkatkan kepercayaan investor.

Struktur modal optimal akan menjadi pilihan terbaik bagi perusahaan, yaitu keadaan dimana dapat meminimalkan nilai cost of capital dan meningkatkan profitabilitas. Struktur modal oprimal merupakan kombinasi terbaik dalam mendatangkan keuntungan. (Brigham \& Houston, 2019) menyebutkan bahwa leverage keuangan dapat meningkatkan ROE yang diharapkan, tetapi semakin besar leverage semakin tinggi risikonya. Jadi, meningkatkan ROE melalui penggunaan leverage belum tentu baik dilakukan. Hasil penelitian ini konsisten dengan penelitian (Khairani, H, 2015) menunjukkan bahwa struktur modal berpengaruh positif dan signifikan terhadap profitabilitas. 
Hasil analisis koefisien determinasi secara parsial menyatakan bahwa kepemilikan manajerial memiliki pengaruh positif dan signifikan terhadap profitabilitas sebesar 30,02\%. Keterlibatan sebagai pemilik saham mengakibatkan manajer akan bertindak hati-hati, karena ikut menanggung konsekuensi atas keputusan yang diambilnya. Selain itu perusahaan dengan kepemilikan manajerial yang lebih tinggi mengurangi konflik antara pemegang saham dan manajer (Shahab-u-Din \& Javid, 2011). Kepemilikan manajerial dapat menyatukan kepentingan antara manajer dengan pemegang saham, sehingga kinerja keuangan perusahaan semakin baik.

Hasil perhitungan koefisien determinasi menyatakan bahwa profitabilitas memiliki pengaruh negatif dan signifikan sebesar $64,8 \%$ terhadap nilai perusahaan. Hal ini tidak sejalan dengan penelitian yang dilakukan oleh (Rista, 2018), (Jusriani \& Rahardjo, 2013), dan (Saraswati, 2016) yang menyebutkan bahwa profitabilitas memiliki pengaruh yang positif terhadap nilai perusahaan. Akan tetapi sejalan dengan penelitian oleh pendapat menurut penelitian (Kusna \& Setijani, 2018) yang juga mendapatkan profitabilitas berpengaruh negatif signifikan terhadap nilai perusahaan.

(Brigham \& Houston, 2019) menyebutkan terdapat tiga masalah yang terjadi apabila perusahaan mengukur pengembalian atas ekuitas (ROE): (1) tidak mempertimbangkan risiko, (2) tidak mempertimbangkan jumlah modal yang diinvestasikan, (3) dapat menyebabkan manajer membatalkan proyek yang menguntungkan. Hini terjadi ketika perusahaan berfokus pada ROE saja.

Perusahaan yang memiliki ROE tinggi sangat diminati investor, sebab menunjukkan adanya jaminan pengembalian atas modal sendiri yang telah diinvestasikan. ROE tinggi juga menunjukkan prospek yang baik di masa depan sehingga dapat meningkatkan kepercayaan para investor. Hal ini disebabkan karena ketika investor akan berinvestasi tidak hanya terpaku pada tingkat keuntungan yang dihasilkan, akan tetapi juga lebih memilih untuk membeli saham perusahaan meskipun tingkat keuntungan mengalami penurunan karena harga saham perusahaan semakin rendah (Kusna \& Setijani, 2018) menyebabkan nilai perusahaan meningkat.

Penurunan suku bunga juga dapat berdampak baik bagi emiten dengan struktur modal yang didominasi oleh hutang, sebab akan langsung berdampak pada pembayaran bunga. Sektor properti rata-rata memiliki hutang lebih besar dari ekuitasnya juga memperoleh manfaat positif, yaitu permintaan properti akan meningkat terutama dari pembeli pertama. Investor mempertimbangkan kondisi pertumbuhan ekonomi untuk berinvestasi, tidak hanya pada ROE. Penelitian ini menunjukkan bahwa ROE tidak dijadikan sebagai acuan investor untuk berinvestasi, sehingga memiliki pengaruh yang negatif.

\section{KESIMPULAN}

Rata-rata peluang tumbuh, struktur modal, kepemilikan manajerial, profitabilitas pada perusahaan jasa sektor properti, real estate, dan konstruksi bangunan yang terdaftar di BEI periode 2012-2018 mengalami kecenderungan menurun, akan tetapi nilai perusahaan cenderung meningkat. Peluang tumbuh, struktur modal, dan kepemilikan manajerial secara simultan dan parsial berpengaruh positif dan signifikan terhadap profitabilitas. Kepemilikan manajerial memiliki pengaruh paling besar. Profitabilitas berpengaruh negatif dan signifikan terhadap nilai perusahaan, profitabilitas tidak dijadikan acuan investor untuk berinvestasi disektor properti, real estate, dan konstruksi bangunan.

\section{DAFTAR PUSTAKA}

Ananda, N.A., 2016. Pengaruh Profitabilitas, Growth Opportunity Terhadap Nilai Perusahaan Dengan Struktur Modal Sebagai Variabel Intervening Pada Perusahaan Property, Real Estate \& Building Construction Di Bei Periode 2011-2014. Jmm Unram-Master Of Management Journal, 5(4).

Awan, A. G., Lodhi, M. U., \& Hussain, D. 2018. Determinants of Firm Value: A Case Study of Chemical Industries of Pakistan. Global Journal of Management, Social Sciences and Humanities, 4(1), 46-61.

Brigham, E. F., \& Houston, J. F. 2019. Fundamentals of Financial Management 15 Edition. Cengage Learning.

Dwipartha, N. M. W. 2011. Pengaruh Faktor - faktor Ekonomi Makro dan Kinerja Keuangan terhadap Nilai Perusahaan. E Jurnal Ekonomi Dan Bisnis, 226-248.

Gitman, Lawrence J. and Zutter, C. J. 2015. Principle of Management Finance (Fourteen). Pearson Education Limited.

Hikmah and Fitria, N. L. 2019. The effect of managerial ownership, institutional ownership, and foreign ownership on intellectual capital. IOSR Journal of Economics Anf Finance, 10(4), 43-48. https:// doi.org/10.14414/tiar.v9i1.1631

Indasari, A. P., \& Yadnyana, I. K. 2018. Pengaruh Profitabilitas, Growth Opportunity, Likuiditas, dan Struktur Modal Pada Nilai Perusahaan. E-Jurnal Akuntansi, 2018(1), 714-746. https:// doi.org/10.24843/EJA.2018.v22.i01.p27

Jusriani, I. F., \& Rahardjo, S. N. 2013. Analisis Pengaruh Profitabilitas, Kebijakan Deviden, Kebijakan Utang, Dan Kepemilikan Manajerial Terhadap Nilai Perusahaan (Studi Empiris Pada Perusahaan Manufaktur Yang Terdaftar Di Bursa Efek Indonesia Periode 2009 2011). Diponegoro Journal of Accounting, 2(2), 168-177.

Kasmir. 2018. Analisis Laporan Keuangan(I). PT. Raja Grafindo Persada. 
Khairani, M., Efni, Y. and Haryetti, H., 2015. Pengaruh Struktur Kepemilikan Manajerial dan Growth Opportunity terhadap Struktur Modal dan Kinerja Keuangan Perusahaan (Studi pada Perusahaan Manufaktur Sektor Industri dan Konsumsi Barang yang Terdaftar di Bei Periode 2009-2012). JOM FEKON, 2(1), 1-14.

Kusna, I., \& Setijani, E. 2018. Analisis Pengaruh Kinerja Keuangan, Growth Opportunity Dan Ukuran Perusahaan Terhadap Struktur Modal Dan Nilai Perusahaan. Jurnal Manajemen Dan Kewirausahaan, 6(1), 93-102. https://doi.org/10.26905/jmdk. v6i1.2155

Mardiyati, U., Ahmad, G. N., Putri, R. 2012. Pengaruh Kebijakan Dividen, Kebijakan Hutang Dan Profitabilitas Terhadap Nilai Perusahaan Manufaktur Yang Terdaftar Di Bursa Efek Indonesia Periode 2015-2017. Jurnal Riset Manajemen Sains Indonesia (JRMSI), 3(1), 1-17. https://doi.org/10.35794/ emba.v8i4.30859

Mayogi, D. G. 2016. Pengaruh Profitabilitas, Ukuran Perusahaan Dan Kebijakan Dividen Terhadap Nilai Perusahaan. Jurnal Ilmu Dan Riset Akuntansi, 5(1), 1-18. https://doi.org/10.21776/ ub.profit.2020.014.02.9

Muntiah, S. 2012. Pengaruh Mekanisme Corporate Governance Terhadap Kinerja Perusahaan (Studi Perusahaan Manufaktur yang Terdaftar di Bursa Efek Indonesia Periode 2010 - 2012). Jurnal Manajemen, 01(01).

Nopiani, K. D., Sulindawati, L. G. E., Sujana, E. 2015. Pengaruh Mekanisme Corporate Governance Terhadap Kinerja Keuangan Bank Perkreditan Rakyat di Bali. Jurnal Akuntansi Program S1, 3(1). https://doi.org/10.21002/jaki.2010.11

Palupi, R. S., \& Hendiarto, S. 2018. Kebijakan Hutang, Profitabilitas dan Kebijakan Dividen Pada Nilai Perusahaan Properti \& Real Estate. Jurnal Ecodemica, 2(2), 177-185. http://ejournal.bsi.ac.id/ ejurnal/index.php/ecodemica

Pasaribu, M., Topowijono, T., \& Sulasmiyati, S. 2016. Pengaruh Struktur Modal, Struktur Kepemilikan Dan Profitabilitas Terhadap Nilai Perusahaan Pada Perusahaan Sektor Industri Dasar Dan Kimia Yang Terdaftar Di Bei Tahun 2011-2014. Jurnal Administrasi Bisnis S1 Universitas Brawijaya, 35(1), 154-164.

Prasetyorini, B. F. 2013. Pengaruh Ukuran Perusahaan, Leverage, Price Earning Ratio dan Profitabilitas terhadap Nilai Perusahaan. Jurnal Ilmu Manajemen (JIM), 1(1).

Putri, V. R., \& Rachmawati, A. 2018. The Effect of Profitability, Dividend Policy, Debt Policy, and Firm Age on Firm Value in The Non-Bank Financial Industry. Jurnal Ilmu Manajemen \& Ekonomika, 10(1), 14. https://doi.org/10.35384/jime.v10i1.59 Rahayu, F. D., dan Asandimitra, N. 2014. Pengaruh
Ukuran Perusahaan, Leverage, Profitabilitas, Kebijakan Dividen Dan Cash Holding Terhadap Nilai Perusahaan Pada Sektor Manufaktur. Jurnal Ilmu Manajemen (JIM), 2(2), 548-561.

Rahman, N.A.A. and Reja, B.A.F., 2015. Ownership structure and bank performance. Journal of Economics, Business and Management, 3(5), pp.483-488.

Rifai, M., Arifati, R., \& Magdalena, M. 2015. Pengaruh Ukuran Perusahaan, Struktur Modal Dan Pertumbuhan Perusahaan Terhadap Profitabilitas Studi Pada Perusahaan Manufaktur Di Bei Tahun 2010-2012. Jurnal Ilmiah Mahasiswa S1 Akuntansi Universitas Pandanaran, 1(2502-7697), 1-8.

Rista, B. 2018. Pengaruh Profitabilitas, Growth Opportunity, Dan Struktur Modal Terhadap Nilai Perusahaan Dengan Good Corporate Governance Sebagai Variabel Pemoderasi. Profita: Komunikasi Ilmiah Akuntansi Dan Perpajakan, 11(2), 306-328.

Rizqia, D. A., Aisjah, S., \& Sumiati. 2013. Effect of Managerial Ownership, Financial Leverage, Profitability, Firm Size, and Investment Opportunity on Dividend Policy and Firm Value. Research Journal of Finance and Accounting, 4(11), 120-130.

Romadon, A.S. dan Sulistyo, H. S. 2018. Peran Profitabilitas dan Good Corporate Governance dalam Memediasu Pengaruh Struktur Modal dan Pertumbuhan Perusahaan Terhadap Nilai Perusahaan. Fokus Ekonomi, 13(2), 210-235.

Saraswati, Y. F. 2016. Pengaruh Growth Opportunity Dan Leverage Terhadap Nilai Perusahaan Dengan Profitabilitas Sebagai Variabel Intervening ( Studi pada Perusahaan Consumer Goods yang Terdaftar di Bursa Efek Indonesia Periode 2011-2014 ). 1-23.

Sardo, F., \& Serrasqueiro, Z. 2018. Intellectual capital, growth opportunities, and financial performance in European firms: Dynamic panel data analysis. Journal of Intellectual Capital, 19(4), 747-767. https://doi.org/10.1108/JIC-07-2017-0099

Shahab-u-Din, \& Javid, A. 2011. Impact of managerial ownership on financial policies and the firm's performance: Evidence Pakistani manufacturing firms. International Research Journal of Finance and Economics, 81(37560), 13-29.

Sofyaningsih, S. dan Hardiningsih, P. 2011. Struktur Kepemilikan, Kebijakan Dividen, Kebijakan Utang, dan Nilai Perusahaan. Dinamika Keuangan \& Perbankan, 3(1). https://www.unisbank.ac.id/ojs/ index.php/fe1/article/view/195

Susanto, E. 2016. Pengaruh Profitabilitas, Kepemilikan Manajerial, dan Pertumbuhan Perusahaan (Growth) Terhadap Struktur Modal dan Nilai Perusahaan. Jurnal STIE Semarang, 8(3), 1-20.

Thaharah, N., \& Asyik, N. F. 2016. Pengaruh Mekanisme Corporate Governance Dan Kinerja Keuangan Terhadap Nilai Perusahaan LQ 45. Jurnal Ilmu Dan Riset Akuntansi, 5(2), 1-18. 
Thi, N., Ha, L., \& Minh, B. T. 2018. Determinants of Firm Value in Vietnam: A Research Framework. International Journal of Science and Research, 9(1), 626-631. https://doi.org/10.21275/ART20204002 Tjandrakirana D. P. 2014. Pengaruh Kinerja Keuangan Terhadap Nilai Perusahaan Pada Perusahaan
Manufaktur Yang Terdaftar di Bursa Efek Indonesia. Jurnal Manajemen Dan Bisnis Sriwijaya, 12(1), $1-16$.

Zondi, S. S. M. 2015. Managerial Ownership and Firm Performance on Selected JSE Listed Firms. Corporate Ownership of Control, 12(3), 233-241.

Tabel 1. Nilai PER Industri per Sektor di BEI Tahun 2011 - 2018 (kali)

\begin{tabular}{lrrrrrrrr}
\hline \multicolumn{1}{c}{ Sektor } & 2011 & 2012 & 2013 & 2014 & 2015 & 2016 & 2017 & 2018 \\
\hline Pertanian & 11,83 & 33,17 & 22,22 & 19,34 & $-1,21$ & 19,38 & 2,52 & 19,27 \\
Pertambangan & 7,39 & 8,5 & 14,43 & 2,9 & 7,77 & 11,35 & 6,21 & $-1,03$ \\
Industri Dasar dan Kimia & 4,64 & 9,79 & 15,28 & 16,6 & 5,32 & 14,32 & 12,88 & 13,74 \\
Aneka Industri & 11,73 & 18,33 & 13,74 & 14,44 & 3,24 & 12,86 & 5 & 16,15 \\
Industri Barang dan Konsumsi & 18,42 & 19,76 & 12,59 & 24,22 & 17,69 & 18,77 & 14,18 & 24,94 \\
Properti, Real estate, dan Konstruksi Bangunan & 12,66 & 17,34 & 15,9 & 16,29 & 18,09 & 23,88 & 14,52 & 27,07 \\
Infrastruktur, Utilitas, dan Transportasi & 6,84 & 17,42 & 21,54 & 17,61 & 14,49 & 10,04 & 15,9 & 9,5 \\
Keuangan & 13,18 & 6 & 16,93 & 28,71 & 22,08 & 20,63 & 19,1 & 25,63 \\
Perdagangan, Jasa, dan Investasi & 19,41 & 16,13 & 17,61 & 21,55 & 12,49 & 18,33 & 13,2 & $-3,08$ \\
\hline Sumber: www.idx.co.id (data diolah kembali, 2019) & & & & & & &
\end{tabular}

Tabel 2. Rata-Rata Perubahan PER Industri Per Sektor di BEI periode 2012-2018 (kali)

\begin{tabular}{lrrrrrrrc}
\hline \multicolumn{1}{c}{ Sektor } & 2012 & 2013 & 2014 & 2015 & 2016 & 2017 & 2018 & Rata-Rata \\
\hline Pertanian & 1,80 & 0,33 & 0,13 & 1,06 & 16,98 & 0,87 & 6,65 & 3,98 \\
Pertambangan & 0,15 & 0,70 & 0,80 & 1,68 & 0,46 & 0,45 & 1,17 & 0,77 \\
Industri Dasar dan Kimia & 1,11 & 0,56 & 0,09 & 0,68 & 1,69 & 0,10 & 0,07 & 0,61 \\
Aneka Industri & 0,56 & 0,25 & 0,05 & 0,78 & 2,97 & 0,61 & 2,23 & 1,06 \\
Industri Barang dan Konsumsi & 0,07 & 0,36 & 0,92 & 0,27 & 0,06 & 0,24 & 0,76 & 0,38 \\
Properti, Real estate, dan Konstruksi Bangunan & 0,37 & 0,08 & 0,02 & 0,11 & 0,32 & 0,39 & 0,86 & 0,31 \\
Infrastruktur, Utilitas, dan Transportasi & 1,55 & 0,24 & 0,18 & 0,18 & 0,31 & 0,58 & 0,40 & 0,49 \\
Keuangan & 0,54 & 1,82 & 0,70 & 0,23 & 0,07 & 0,07 & 0,34 & 0,54 \\
Perdagangan, Jasa, dan Investasi & 0,17 & 0,09 & 0,22 & 0,42 & 0,47 & 0,28 & 1,23 & 0,41 \\
\hline
\end{tabular}

Sumber : www.idx.co.id (data diolah kembali, 2019)

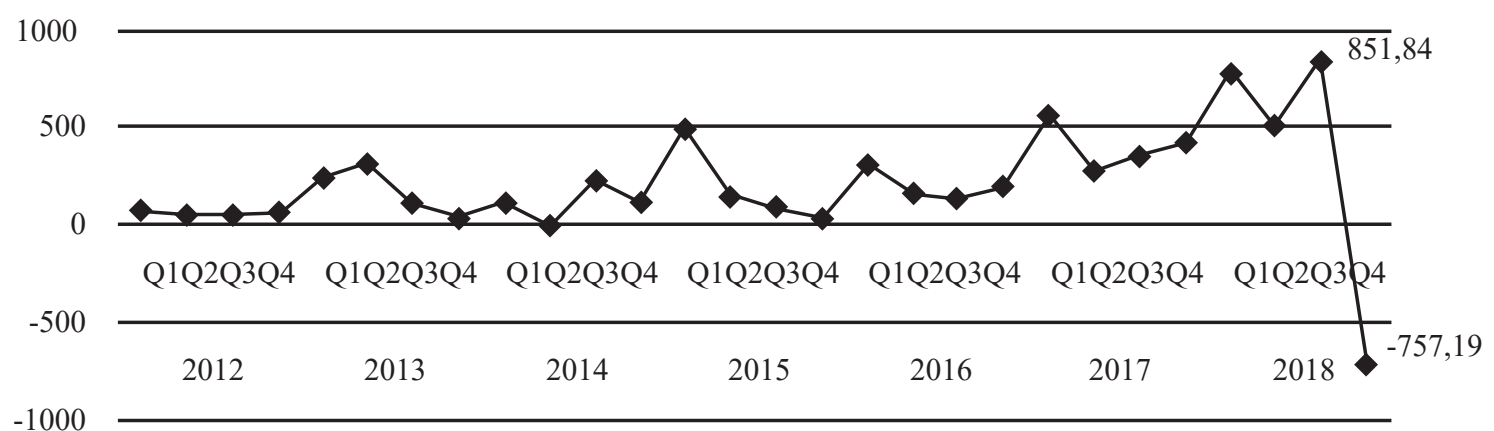

Gambar 1. Rata-Rata PER Pada Perusahaan Jasa Sektor Properti, Real Estate, dan Konstruksi Bangunan Periode 2012 - 2018 (kali) 


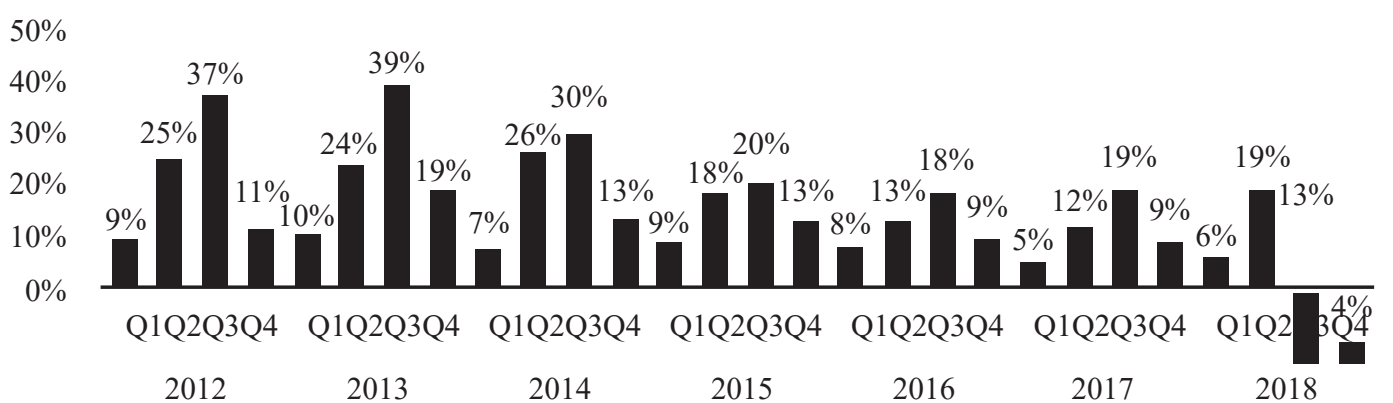

Gambar 2. Rata-Rata Profitabilitas (ROE) Perusahaan Jasa Sektor Properti, Real Estate, dan Konstruksi Bangunan yang terdaftar di BEI Periode 2012-2018

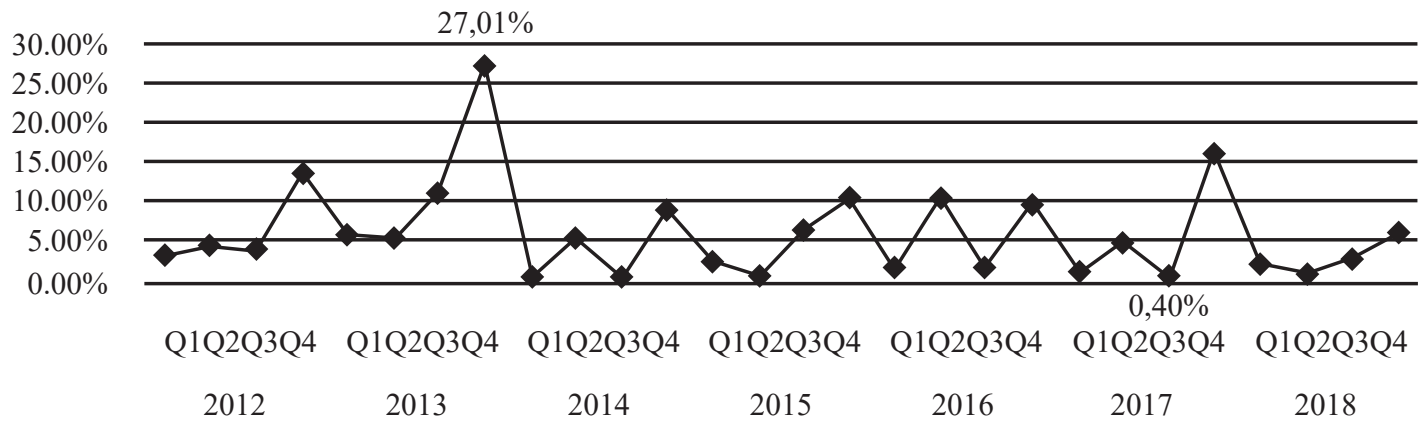

Gambar 3. Rata-Rata Growth Assets Perusahaan Jasa Sektor Properti, Real Estate, dan Konstruksi Bangunan yang terdaftar di BEI Periode 2012-2018

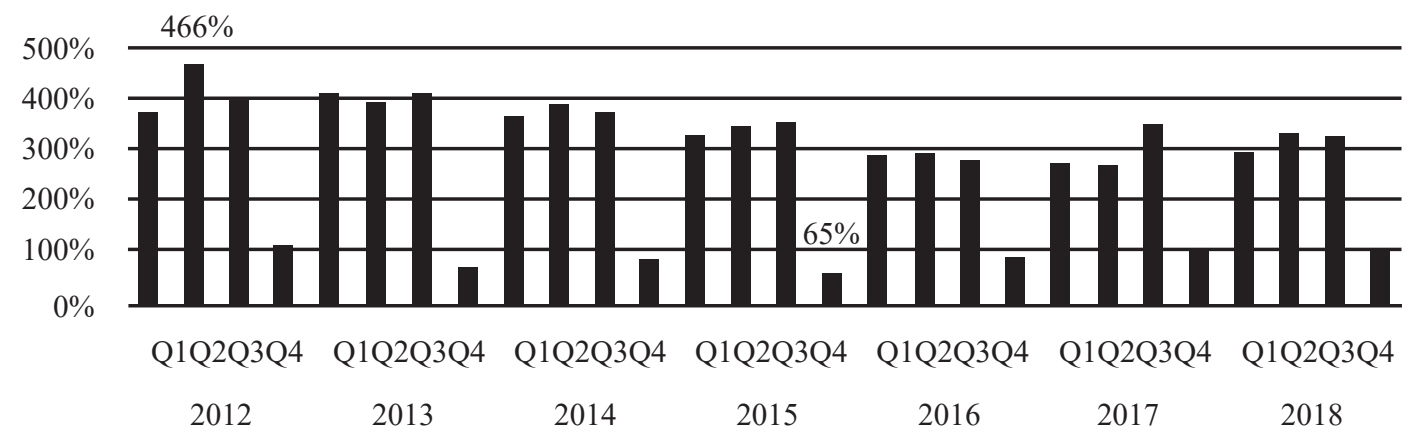

Gambar 4. Rata-Rata Nilai Struktur Modal (DER) Perusahaan Jasa Sektor Properti, Real Estate, dan Konstruksi Bangunan yang terdaftar di BEI Periode 2012-2018

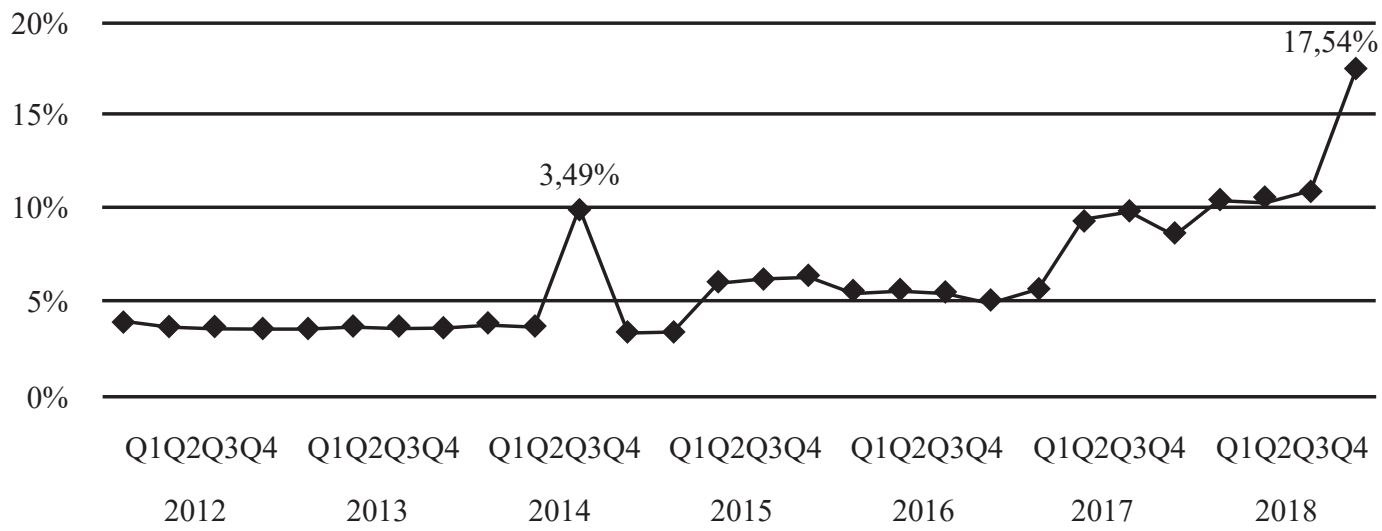

Gambar 5. Rata-Rata Kepemilikan Manajerial (Managerial Ownership) Perusahaan Jasa Sektor Properti, Real Estate, dan Konstruksi Bangunan yang terdaftar di BEI Periode 2012-2018 
Tabel 3. Hasil Regresi untuk Persamaan 1

Coefficients $^{\text {a }}$

\begin{tabular}{|c|c|c|c|c|c|c|c|c|c|}
\hline \multirow[b]{2}{*}{ Model } & & \multicolumn{2}{|c|}{$\begin{array}{c}\text { Unstandardized } \\
\text { Coefficients }\end{array}$} & \multirow{2}{*}{$\begin{array}{c}\begin{array}{c}\text { Standardized } \\
\text { Coefficients }\end{array} \\
\text { Beta }\end{array}$} & \multirow[b]{2}{*}{$\mathrm{t}$} & \multirow[b]{2}{*}{ Sig. } & \multicolumn{3}{|c|}{ Correlations } \\
\hline & & $\mathrm{B}$ & Std. Error & & & & Zero-order & Partial & Part \\
\hline \multirow[t]{4}{*}{1} & (Constant) &, 024 &, 015 & & 1,624 &, 112 & & & \\
\hline & PeluangTumbuh & 621 &, 175 & ,392 & 3,556 & ,001 & ,261 & ,472 & ,382 \\
\hline & Struktur Modal & 032 &, 010 & ,362 & 3,300 &, 002 & 248 & ,445 & 354 \\
\hline & Kepemilikan Manajerial & 2,334 & ,434 &, 583 & 5,372 &, 000 & ,515 & 629 & ,577 \\
\hline
\end{tabular}

a. Dependent Variable: Kinerja Keuangan

Tabel 4. Hasil Regresi untuk Persamaan 2

Coefficients $^{\mathrm{a}}$

\begin{tabular}{|c|c|c|c|c|c|c|c|c|c|}
\hline \multirow[b]{2}{*}{ Model } & & \multicolumn{2}{|c|}{$\begin{array}{c}\text { Unstandardized } \\
\text { Coefficients }\end{array}$} & \multirow{2}{*}{$\begin{array}{c}\begin{array}{c}\text { Standardized } \\
\text { Coefficients }\end{array} \\
\text { Beta }\end{array}$} & \multirow[b]{2}{*}{$\mathrm{t}$} & \multirow[b]{2}{*}{ Sig. } & \multicolumn{3}{|c|}{ Correlations } \\
\hline & & $\mathrm{B}$ & Std. Error & & & & Zero-order & Partial & Part \\
\hline 1 & (Constant) & 35,167 & 2,625 & & 13,398 &, 000 & & & \\
\hline & Unstandardized Residual & $-201,951$ & 73,582 &,- 375 & $-2,745$ & 009 &,- 375 &,- 375 &,- 375 \\
\hline
\end{tabular}

a. Dependent Variable: Nilai Perusahaan

Tabel 5. Hasil Koefisien Determinasi untuk Persamaan 1

Model Summary ${ }^{\mathrm{b}}$

\begin{tabular}{cccccc}
\hline Model & R & R Square & Adjusted R Square & Std. Error of the Estimate & Durbin-Watson \\
\hline 1 &, $702^{\mathrm{a}}$ &, 492 &, 458 &, 03726 & 1,065 \\
\hline
\end{tabular}

a. Predictors: (Constant), Kepemilikan Manajerial, Struktur Modal, Peluang tumbuh

b. Dependent Variable: Profitabilitas

Tabel 6. Perhitungan Koefisien Determinasi Parsial

\begin{tabular}{lcccc}
\hline \multicolumn{1}{c}{ Variabel } & Nilai b & Zero Order & $\mathrm{r}^{2}$ & Besar Pengaruh \\
\hline Peluang Tumbuh & 0,392 & 0,261 & 0,1023 & $10,23 \%$ \\
Struktur Modal & 0,362 & 0,248 & 0,0898 & $8,98 \%$ \\
Kepemilikan Manajerial & 0,583 & 0,515 & 0,3002 & $30,02 \%$ \\
\hline Jumlah & & & $49,23 \%$ \\
\hline
\end{tabular}

Tabel 7. Hasil Koefisien Determinasi untuk Persamaan 2

Model Summary

\begin{tabular}{lcccc}
\hline Model & $\mathrm{R}$ & $\mathrm{R}$ Square & Adjusted R Square & Std. Error of the Estimate \\
\hline 1 &, $805^{\mathrm{a}}$ &, 648 &, 628 & 4,01296 \\
\hline
\end{tabular}

a. Predictors: (Constant), Profitabilitas

Tabel 8. Hasil Uji Signifikansi Simultan (Uji F) untuk Persamaan 1

ANOVA $^{\mathrm{a}}$

\begin{tabular}{llccccc}
\hline Model & & Sum of Squares & df & Mean Square & F & Sig. \\
\hline 1 & Regression &, 059 & 3 &, 020 & 14,227 &, $000^{\mathrm{b}}$ \\
& Residual &, 061 & 44 &, 001 & & \\
& Total &, 120 & 47 & & & \\
\hline
\end{tabular}

a. Dependent Variable: Profitabilitas

b. Predictors: (Constant), Kepemilikan Manajerial, Struktur Modal, Peluang Tumbuh 
Tabel 9. Hasil Uji Signifikansi untuk Persamaan 2

ANOVA $^{\mathrm{a}}$

\begin{tabular}{llccccc}
\hline Model & & Sum of Squares & df & Mean Square & F & Sig. \\
\hline 1 & Regression & 2490,995 & 1 & 2490,995 & 7,533 &, $009^{\mathrm{b}}$ \\
& Residual & 15211,671 & 46 & 330,689 & & \\
& Total & 17702,667 & 47 & & & \\
\hline
\end{tabular}

a. Dependent Variable: Nilai Perusahaan

b. Predictors: (Constant), Unstandardized Residual 